\title{
Portugal, \\ de minha varanda
}

Alberto da Costa e Silva*

\footnotetext{
* Ensaísta, poeta e Embaixador do Brasil em Portugal.
} 
Creio que foi E ugenio d'Ors quem, a propósito de Portugal, Espanha e Rússia, disse, com outras palavras, que não se pode ser impunemente o fim de um mundo. Nem o fim de um mundo, nem o começo de outros. Paga-se o preço de se ser fronteira não só com as angústias do abismo, da dúvida e da incerteza, as obrigações da aventura e os conseqüentes dramas da viuvez e da orfandade, mas também com o dever de ser fiel a seu mundo e de ganhar para ele os demais. Custa mais caro ainda, quando esses lindes, como no caso de Portugal, terminam no riscar das praias e das falésias. E se, depois, em vez de correrem sobre a terra, forem desenhar-se nos oceanos, cada vez mais distantes e mais extensos, e de tal modo que seus pontos de conflito acabarão por demorar-se na entrada do rio da Prata, na boca do mar Vermelho e no estreito de Malaca. Porque assim se deu, Portugal, durante quase dois séculos, foi ao mesmo tempo, econômica, política e militarmente, um país do Índico e um estado europeu.

Ainda que se aquiete o impulso de expansão e refluam os limites do Índico e do Atlântico para as costas européias, ficarão do avanço mais que memória e descendência. Pois a história não se apaga e só raramente o que foi não prossegue no que é. Assim, quando no Ceilão alguém diz ser Sousa o seu nome de família ou, em Lagos, na Nigéria, um menino responde "I don't sabe" em vez de "I don't know", pode-se confundir com pequeninos fósseis ou conchas vazias na areia o que são marcas de uma presença subterrânea, insuspeita e até incompreendida, mas íntima, permanente e inapagável.

É bem verdade que estamos diante, algumas vezes, de simples rabiscos na pedra feitos por grupos de passagem. A miúde, porém, são a persistência ou a continuidade da presença lusitana e das viagens portuguesas pelas mais diversas ge- 
ografias, e poderiam comparar-se às mangueiras nas Américas, aos cajueiros na África ou aos batatais na Europa, tão à vontade na paisagem, que parecem nativos, mas foram trazidos de outros continentes. Pode até mesmo suceder que determinado jeito de pentear os cabelos, aquela maneira de sentar-se, certo desenho dos canteiros do jardim e isto e aquilo que pertencem ao dia-a-dia, tenham ficado com o sangue de um ou mais degredados descidos numa praia. A herança importada tende a deixar de ser estrangeira e de tal modo se imiscui no novo ambiente, que passa impressentida, como as comparações, as metáforas, as personagens, os versos ou os episódios da l líada e da Odisséi a que estão em todos os livros que escrevemos, na nossa E uropa e na nossa América, desde Homero.

O que foi legado, contudo, nem sempre se embuça ou se faz despercebido. R evela-se freqüentemente com franqueza e nitidez. E ntro, caminhando, por uma rua da Baixa, no Porto, e posso, ao dobrar uma esquina, sair em outra, bem no centro do R io de J aneiro, não sentindo, aqui e ali, mais que alguma pequena diferença. E, se tivesse como transportar uma igreja de Braga para M inas G erais ou um frontão do Aleijadinho para um templo minhoto, nem uma nem o outro destoariam de seu novo espaço, porque feitos com a mesma técnica, a mesma intenção e o mesmo gosto.

Por mais de cinco séculos, o português, para onde quer que fosse, carregou no baú a sua terrinha. $\mathrm{E}$, onde isto Ihe foi possível, misturou-a com o solo alheio. Tanto nos países do exílio quanto em sua leiva européia, pôs também o que trouxe de outros lados no alforje. Fez seus o caril, a rede, a malagueta, o quimono - e foi abrindo espaços para a América na Europa, para a África na América, para a Europa na Ásia e para cada um dos continentes em todos os demais. Outros lhe seguiram a lição: os espanhóis e italianos, nos calcanhares; os holandeses, ingleses e franceses, vários passos atrás, mas com igual ou maior pressa. E Ihe forçaram o recuo.

Se, entretanto, ao longo da história, se foram contraindo os limites do império e se reduziu o âmbito de interesse direto político, diplomático e militar de Portugal, não pararam as suas gentes de chegar, como mercadores ou imigrantes, a pelo menos algumas das terras de que tinham, de uma forma ou de outra, tomado posse no passado.

E is o B rasil. Mais portugueses desembarcaram em seus portos após a independência do que nos tempos da colônia. Perto de dois milhões, entre 1822 e os nossos dias. No passar dos séculos e das décadas, eram e não eram a mesma gente. Primeiro, porque se foram mudando os pontos de partida: da E stremadura, do Alentejo, do Algarve e dos A çores, no início do povoamento, para o D ouro, o M inho, o Trás-os-M ontes, as B eiras e a M adeira. Depois, porque cada geração de migrantes vinha aparelhada de modo diferente das que Ihe antecederam. E ra, de certa for- 
ma, a cada novo momento, modernizadora. Nas técnicas ou na mentalidade. No que sabia fazer, no que esperava encontrar, e na ambição, e no sonho.

Pensando bem, eram poucos. Sempre tinham sido poucos. Durante a colônia, duzentos, quinhentos, mil, anualmente. Mesmo no auge da imigração, nas duas primeiras décadas deste século $X X$, não chegaram a trinta mil por ano. 0 que tinham era uma enorme capacidade de aportuguesar os outros e multiplicarse nos mestiços, nos clientes, nos agregados e nos escravos. Como, séculos antes, nos seus respectivos impérios, os romanos e os árabes. A prova clara: a um Brasil habitado por alguns milhões de ameríndios (tupis, gês, caribes, aruaques), vieram ter entre 3 e 5 milhões de africanos (congos, ambundos, ovimbundos, iorubas, fons, hauçás, mandingas, fantis, macuas), cerca de 3 milhões de europeus nãoportugueses (italianos, espanhóis, alemães, russos, austríacos, polacos, suíços) e centenas de milhares de japoneses, árabes e arabizados, coreanos e chineses, mas em todo o país (um país que foi, por muito tempo, uma espécie de arquipélago, com enormes extensões de terra a afastar as ilhas de povoamento) fala-se uma só língua, o português. E, qualquer que seja a sua origem, é na terra portuguesa que o brasileiro identifica sua raiz axial ou, quando menos, uma das partes mais profundas e grossas de seu raizame.

Conto duas das numerosas histórias que vivi ou sei. Há alguns anos, quando eu era embaixador em Lisboa, veio jantar comigo um antigo professor, o geógrafo brasileiro Hilgard O'R eilly Sternberg. Chegara na mesma tarde, emocionado, do Minho e da Beira. E disse-me: "Não tenho uma gota de sangue português. Mas sinto-me como se fosse desta terra. Vou à I rlanda ou à Alemanha e lhes admiro a paisagem, porém como espectador, sem comover-me. Aqui, estremeço diante de um casario e dos campos lavrados. Pois minha sensibilidade é portuguesa. Formei-a lendo Camões, Eça, Nobre e Camilo, e é deles que trago o sentimento da paisagem. As memórias de meu espírito é aqui que as reencontro."

Algo muito parecido passou-se com um grande escritor brasileiro, o contista Samuel Rawet. Os pais o trouxeram, menino de dois anos, da Polônia para o Rio de J aneiro. E só adulto, voltou à Europa. Estivera a trabalhar, como engenheiro especializado em cálculos de concreto, em projetos de O scar Niemeyer, em I srael. Na volta, após passar de raspão por Paris, parou em Lisboa. E teve a sensação de um reencontro feérico. Deixou-se ficar na cidade, em ócio - estava em casa - , por alguns meses. E não perdeu um só dia sem emocionar-se, diante de uma janela, de uma escadaria, de um beco, de uma nesga do Tejo, com o que sabia ser parte da biografia de sua alma. Como se o Portugal que havia no B rasil, e ele redescobrira na E uropa, Ihe lavasse o corpo de outras memórias.

Se um brasileiro - e acredito que também muito angolano, cabo-verdiano ou goês - continua em terra conhecida ao pisar Portugal, o mesmo sucede ao portu- 
guês, ao descer em Belém, Recife, Salvador ou Porto Alegre. O u em Luanda, B enguela ou B eira. E le está em solos de sua história. E pode sentir o peito apertado por uma espécie de saudade do que foi e do que podia ter sido. E não só nessas paragens onde se fala português, mas também em outras, das quais o idioma foi expelido. Como nas ruas com sobrados, meias-moradas e porta-e-janelas do B razilian Quarters de Lagos, na Nigéria. Ou nas praças da Colônia do Sacramento, no Uruguai. Aqui, ali, acolá, nas Américas, nas Áfricas, nas Ásias, por toda a parte.

Quem buscou o mundo por destino - de início, como navegador, e depois, como colono e emigrante - não poderá resignar-se a voltar aos tempos em que não inventara a caravela. A ser apenas um pedaço da Europa. Só com muito esforço poderá desvincular-se de seu fado de ter sido e continuar a ser fronteira. De haver, de certa forma e a seu jeito, inventado para a E uropa os oceanos. E de ter construído um extenso império, que nem por haver minguado lentamente, ao longo dos séculos, deixou de ser, exceto em suas derradeiras décadas, um verdadeiro império, uma soma, um todo, dentro do qual, apesar dos privilégios dos metropolitanos, um goês podia ser juiz, um caboverdiano, governador, e um brasileiro, ministro do reino.

Desde o Quinhentos, esse imenso espaço foi o campo de aventura e esperança dos portugueses e de seus descendentes. Era nele- e sobretudo, após 1822, nos territórios africanos - que Portugal identificava o seu futuro. Mas, antes mesmo de que o império, já em nossos dias, se desmanchasse de todo e se impusesse o desenho de novos rumos, o país, para romper o relativo isolamento resultante da guerra colonial e participar da construção do que se queria fosse um novo tipo de E uropa, fez-se membro da EFTA, de uma EFTA que representou para seus sócios uma espécie de rito de passagem para a CEE.

Não apenas por necessidade, conveniência e escolha, Portugal participa da União Européia, mas igualmente por um imperativo de sua posição no planeta. Por uma aposta no que tem por futuro. Isso não significa, contudo, amarrar ao cais as suas naus, nem excluir de seu convívio outras partes do mundo, sobretudo aquelas de que foi matriz ou metrópole e com as quais divide o uso do mesmo idioma. Tampouco reclama-se do B rasil que abandone sua vocação atlântica, por ter como projeto prioritário o M ercosul e a integração econômica com seus vizinhos de hemisfério. O reconhecer-se que o B rasil, geograficamente, limita a leste com a África e, historicamente, com esta e com a Europa, só robustece os seus méritos de sócio numa zona de livre comércio, num mercado comum ou num processo mais íntimo de coesão continental.

Parece-me claríssimo que Portugal tem mais valia para a União E uropéia como um país com fortes vínculos em outros continentes do que desacompanhado. Não se 
trata de um parceiro a mais, espremido entre a E spanha e o Atlântico, com escassos recursos e economicamente pobre - pobre que sempre foi, até mesmo quando parecia enriquecido pela pimenta da Índia e o ouro do Brasil. Trata-se de um país que se construiu não apenas no extremo ocidental de uma península da Ásia, mas nos quatro cantos da terra, neles deixando marcas, na maioria dos casos, profundas. De um país robustamente aglutinante, que não abriga os dissensos, que seus sócios conhecem, de idiomas, regionalismos e etnias, nem encerra, num território cuja forma em quase nada se alterou desde o fim do século XIII, enclaves de outras nações.

A propensão para aproximar, vincular, atar, unir e homogeneizar, os portugueses a levaram mundo afora. Com o que tinham de marinheiro, desprezavam a rotina, amavam a diversidade e se acomodavam às novas geografias e ao exótico das gentes e dos costumes; mas o seu lado lavrador só se afazia ao divergente com o intuito de convertê-lo, assimilando-o, modificando-Ihe a natureza ou, em última instância, repelindo dele o que Ihe aborrecia. Assim, após aprender o abaenhenga ou o nheengatu e permitir a seus filhos e netos que quase só se expressassem nesses idiomas, o português foi impondo pouco a pouco o seu vernáculo, até sentir-se suficientemente forte para proibir, em 1757 e 58, que se falasse em público, nos seus Brasis, outra língua que não a sua. (E transmitiu esse espírito uniformizador aos brasileiros, que repetiriam o interdito, diante da ameaça de um quisto alemão no sul do país, em 1942.)

Estamos quase sempre diante de um punhado de forasteiros que se propunham a converter à sua cultura a numerosa gente da terra. O u se esforçavam para que não se alterassem os modos de vida que os portugueses que os haviam precedido tinham tornado prevalecentes. O principal instrumento, para lograr qualquer desses objetivos, era a família. Cada colono ou imigrante aumentava, multiplicava, potenciava o seu número, ao unir-se com várias mulheres locais e ter com elas dezenas e até, em alguns poucos casos, centenas de filhos - os paradigmas históricos, no Brasil, são J oão Ramalho, Diogo Álvares Correia e J erônimo de Albuquerque -, ao incorporar à família, como se fossem de seu sangue, os cunhados, os concunhados, os rebentos de uns e de outros, com suas esposas e sua prole, e ao fazer, de afilhados, sobrinhos, de agregados, afilhados, e de ex-escravos, clientes. Assim aportuguesaram-se ameríndios e descendentes de africanos, mamelucos e mulatos, ao mesmo tempo que os portugueses iam insensivelmente adquirindo traços do Brasil e da África.

Desde a época da colônia até à metade deste século $X X$, era difícil encontrarse no Brasil quem não tivesse na família um português ou uma portuguesa. (Hoje, já não é tão comum, mas tampouco é raro; eu, por exemplo, tenho um cunhado de Penafiel e uma nora lisboeta). R efiro-me a um tipo de família - esclareça-se - que era mais extenso do que a família extensa dos antropólogos e sociólogos, porque 
nela se podia incluir a tia beiroa de um genro ou o padrinho madeirense da muIher. É bem provável que esses fortes vínculos afetivos ou de interesses entre famílias brasileiras e seus integrantes ou fundadores portugueses expliquem o não se haverem aprofundado, nem terem persistido no tempo, os ressentimentos pela violência, a rapina, a tributação voraz, o tratamento desigual entre reinóis e mazombos e todas as grandes e pequenas ignomínias que também acompanharam os descobrimentos, as conquistas e a colonização.

Antes da independência, durante o seu processo e logo depois, prolongando-se em certas áreas por várias décadas (em Pernambuco, por exemplo), houve, no $B$ rasil, um forte sentimento antiportuguês. Q ue assumiu algumas vezes feições violentas, como em 1831 e no "mata-marinheiro" da R evolução Praieira. De um modo geral, no entanto, a animosidade, quando se manifestava, tinha por alvo os portugueses que não eram os nossos, os da nossa família, distinguia entre eles e os demais e, muitas vezes, entre os peninsulares recém-chegados ou que continuavam unidos aos interesses da antiga M etrópole e aqueles que se haviam aclimatado e rendido ao B rasil. Estes últimos, quando criticados, descompostos, maltratados ou agredidos, sempre encontraram defensores. Para cada Antônio Torres não faltou nunca meia dúzia de J oões do Rio.

A birra em relação aos portugueses - ou, menos que implicância, a afirmação da diferença - assumiu uma bem humorada forma pública, nos contos jocosos envolvendo o "galego", o "novato", o “labrego", o "marinheiro", o “cutruca”, o "péde-chumbo", o "talaveira". A inda não se escreveu um estudo histórico e sociológico sobre a anedota de português - do tipo que Gilberto Freyre dedicou à doçaria do Nordeste, Luís da Câmara Cascudo à rede-de-dormir, E duardo F rieiro ao tutude-feijão e à cozinha mineira, Mário Souto Maior à cachaça e Mauro Mota aos rótulos de cigarros. Desconfio que talvez descubramos, quando isso se fizer, que algumas das mais antigas dessas historietas não passam de adaptações das que os portugueses contavam sobre os galegos. Só que a palavra galego, no Brasil, além de aplicada na acepção própria aos imigrantes da Galiza, estendeu-se, depreciativamente, primeiro aos minhotos e, depois, a todos os portugueses.

O principal alvo da anedota não era o português já de pazes feitas com os costumes brasileiros, moldados em grande parte pelos seus antecessores. Era o "novato", o "marinheiro", o imigrante recém-vindo de sua aldeia nortenha, que mal conhecia os usos das cidades e só passara pelo Porto para embarcar no navio. Vestido de lã pesada, ignorante dos hábitos dos trópicos, dos comportamentos da sociedade a que chegava e dos imprevistos significados que nela haviam assumido certos gestos e certas palavras que Ihe eram habituais, embasbacado diante das novidades, explorado pelos que o recebiam, trabalhador sem folgas e cheio de determinação, muitas vezes teimoso ou suspicaz, ávido por superar a pobreza e, 
por isso, mais que frugal, avaro, ou a equilibrar-se no limite entre a parcimônia e a sovinice, analfabeto ou quase, logrando, porém, no B rasil, por seu próprio esforço, galgar diferentes degraus de instrução, e empregando a lógica rural no contexto urbano, fez-se ridículo junto aos brasileiros e aos cúmplices destes no fabrico das piadas, os portugueses já antigos na terra, ansiosos por contar "a última do patrício". A caçoada mirava, e mira, um dos nossos, o familiar que chegava diferente - e até na maneira de exprimir-se no mesmo idioma, com pronúncia difícil de entender-se, porque sem vogais intermediárias, como se as palavras fossem compostas quase só de consoantes. De que disso se trata, dão-nos os riograndenses-do-sul uma boa pista: chamavam aos portugueses "talaveira". O vocábulo significa também um indivíduo que mal sabe montar a cavalo, isto é, que não monta a cavalo à maneira de um gaúcho.

Se a origem rural de quase toda a imigração portuguesa entre 1850 e 1950 - e foi todo um século -, deixou esse esboço simplista de um rústico pouco flexível, duro de entendimento e obstinado, mas ativo e empreendedor, sedimentou ela na opinião geral dos brasileiros uma imagem de Portugal que, não deixando de ser verdadeira, foi purificada pela saudade. Saíramos também nós, os brasileiros, de um jardim do éden "à beira-mar plantado". De um país de pequenas cidades, aldeias e quintas floridas, de lugares que tinham na essência, embora diferentes como são diferentes a M adeira de Trás-os-M ontes e o M inho das B eiras -, o mesmo gosto de água fresca de Tormes, a mesma claridade e colorido de um dos livros mais amados pelos brasileiros, A Cidade e as Serras. Lisboa, para a maioria da nossa gente, era apenas uma agradável escala para Paris. Mas ao vilarejo de onde o pai ou o avô tinham vindo de socos ou tamancos, na 3 a classe ou na coberta de um navio, e que era o mesmo onde os bem sucedidos, ou seus filhos e netos, iam procurar, não suas ascendências descalças, porém antepassados condes ou morgados (reais, presumíveis ou imaginários), chegava-se com o coração a derramarse.

Para não poucos, a idéia de Portugal era a de um país pequenino, simples, altivo e belo, cuja história nos fazia herdeiros de heróis. A de um país afetivamente tão perto do B rasil, que dele mais parecia um pedaço que se deixara ficar do outro lado do oceano. Essa imagem de Portugal era reforçada pela organização da nostalgia. Reunidos em associações como as casas dos poveiros, dos Açores ou das B eiras, os imigrantes, envaidecidos de suas origens rurais, buscavam conservar e difundir as músicas, as danças, as comidas e os costumes populares de cada uma de suas regiões. Daí certas persistências curiosíssimas. Na A marante natal de meu país, no Piauí, cantam-se, por exemplo, os mesmos versos a São G onçalo que na A marante portuguesa, e, nos dias de festa, ganham as ruas grupos de mocinhas que poderiam, pelos trajes tradicionais, ter desembarcado do Douro. 
Os clubes portugueses desse tipo não eram, nem são, contudo, as únicas estâncias da saudade. Outras ajudaram a retocar ou corrigir o retrato que de Portugal se ia fixando entre o comum dos brasileiros: as beneficências portuguesas, os liceus literários, os gabinetes de leitura, os jornais comunitários. Os três últimos tipos de instituição dão testemunho de um comércio intelectual transoceânico que data dos tempos da colônia e faz com que pertençam à história da cultura de ambas as nações um Padre Antônio Vieira, um A lexandre de G usmão, um Tomás Antônio G onzaga, um Alexandre Rodrigues Ferreira, um Domingos Caldas Barbosa, um G onçalves Crespo e um Waldemar da Costa.

Para a inteligência brasileira, que teve, durante quase três séculos, Coimbra por sinônimo de universidade, a visão de Portugal era muito mais complexa. Acompanhavam-se com atenção a vida política e a vida cultural portuguesas. As revistas e os livros publicados em Lisboa e no Porto chegavam com regularidade às livrarias que serviam a um grupo reduzido mas interessado de leitores, em B elém, São Luiz, R ecife, Salvador, R io de J aneiro, B elo Horizonte, São Paulo e Porto Alegre. As companhias de teatro e os atores portugueses incluíam o Rio de J aneiro e, algumas vezes, outras cidades em suas temporadas. E, até às primeiras décadas deste Novecentos, era no B rasil que muitos escritores portugueses, a começar por Eça de Queirós, tinham a maior parte de seu público. Em compensação, era em Portugal que alguns autores brasileiros, entre os quais Coelho $\mathrm{N}$ eto, editavam as suas obras.

A fuga da rotina, o gosto da aventura, o estímulo de novas oportunidades ou as vicissitudes políticas - e não por acaso Fernando Pessoa exilou o monárquico $\mathrm{R}$ icardo Reis no Brasil - trouxeram para as cidades brasileiras escritores, pensadores, artistas plásticos, professores, músicos e jornalistas, muitos da mais alta qualidade e, alguns, dos mais notáveis da história da cultura portuguesa, em cujas bagagens vieram novas maneiras de pensar e de julgar, novos conceitos estéticos, novas técnicas criadoras. E não foram poucos os dentre eles que exerceram um magistério renovador. Ao reduzir a lista a uma dezena de nomes, tenho Rafael Bordalo Pinheiro, Arthur Napoleão, Carlos Malheiro Dias, Correia Dias e, mais tarde, a refugiarem-se do salazarismo ou da Segunda G uerra M undial, J aime Cortesão, Maria Helena Vieira da Silva, Fidelino de Figueiredo, Agostinho da Silva, Adolfo Casaes Monteiro e J orge de Sena. E nem faltou um caso muito especial: o de J oão G aspar Simões, que, sem ter jamais morado no B rasil, foi como se tivesse vivido no país por alguns anos, aqueles em que respondeu, sem sair de Lisboa, pela crítica de livros brasileiros num dos maiores jornais cariocas.

Ainda está por contar-se o quanto esses exilados fizeram, sobretudo durante a G uerra, para que as novas gerações brasileiras não se apartassem da cultura portuguesa e tivessem acesso ao que de novo se fizera e se fazia em Portugal. 
Continuam também à espera de reconhecimento o trabalho realizado por António de Souza-Pinto, com a sua Livros do B rasil, em Lisboa, na difusão dos autores do modernismo brasileiro, e por António Pedro Martins R odrigues, com a sua Livros de Portugal, no Rio de J aneiro. Foi este último quem editou, em 1944, uma antologia de Cecília Meireles, Poetas Novos de Portugal, na qual se entregou Fernando Pessoa ao grande público brasileiro, que imediatamente o reconheceu - e talvez antes de que o fizessem os portugueses - como um dos maiores poetas do idioma. E não foi em Lisboa que Cecília editou, em 1939, Viagem, sendo ali recebida como grande poetisa, primeiro que no Brasil?

Esse convívio tem sido intercalado por períodos, geralmente breves, de afastamento ou indiferença. Cada um dos dois países, de tempos em tempos, como que redescobre o outro para o seu entusiasmo. Às vezes, como resultado da presença de fortes personalidades, como foi o caso de R ibeiro Couto, em Portugal, e o de Agostinho da Silva, no Brasil. Mas quase sempre, pela recepção das obras de um no território do outro. Abre-se, num lado do Atlântico, um amplo espaço de admiração para as criações surgidas além oceano - tal qual se deu com, entre tantos outros, A ntónio Sérgio, M anuel B andeira, A Imada Negreiros, J orge de Lima, Ferreira de Castro, J osé R égio, Vitorino Nemésio, Carlos Drummond de Andrade, É rico Veríssimo, M iguel Torga, G ilberto Freyre, J orge Amado, J osé Lins do R ego, Graciliano R amos, Portinari, Carlos B otelho, J oão Villaret, Vieira da Silva, Clarice L ispector, Vergílio Ferreira, G uimarães R osa e J osé Saramago - , os desta margem influenciando os daquela e sendo influenciados de volta - e vão de exemplos Fernando Pessoa, Villa-Lobos, Aquilino R ibeiro, o teatro brasileiro do A pós-Guerra, J oão Cabral de M elo N eto e os poetas do concretismo.

Esse subir e baixar de marés dá-se também em outros planos. No dos investimentos financeiros, por natureza flutuantes, mas, às vezes, mais dinâmicos do que as transações comerciais, que sempre foram magras e mornas. Durante o século que vai até quase 1970, o Brasil, exportador de produtos primários, pouco tinha que oferecer a um Portugal com colônias tropicais. Portugal, por sua vez, vendia ao Brasil artigos que paulatinamente foi deixando de produzir em quantidades suficientes para atender a seu próprio consumo interno (bacalhau seco, sardinhas enlatadas, azeite de oliva, azeitonas) e outros que, sazonais, atendiam à saudade dos imigrantes ou às exigências das ceias de fim de ano (vinhos, passas, castanhas, nozes, avelãs), quando - para usar a frase que ouvi do escritor chileno J orge Guzman - o Natal ainda era Natal e não se transformara em Christmas.

As mudanças nas estruturas econômicas dos dois países - com o Brasil tornando-se um exportador sobretudo de bens industriais e Portugal concedendo tratamento preferencial, primeiro aos países da EFTA e depois a seus parceiros da União E uropéia - não repercutiram num aumento expressivo das trocas entre 
os dois países. E as várias medidas ajustadas, com esse objetivo, entre os dois Governos, de pouco resultaram, uma vez que a iniciativa privada não se mostrou animada a trabalhar um mercado que considerava fechado por excessivo protecionismo, como o do Brasil, ou que Ihe parecia pequeno demais, como o português, para valer o esforço e o risco. E nisto estamos - e possivelmente continuaremos por algum ou muito tempo, a sofrer uma sensação crônica de impotência e abatimento, com um único aspecto menos cinza nas estatísticas comerciais: o da importância das exportações de livros, embora os seus números fiquem muito aquém do crescimento do universo de leitores em cada um dos dois países.

No plano político, como, de resto, em todos os outros, o diálogo entre Portugal e o Brasil deixou de dar-se, desde meados do século XIX, entre uma ex-metrópole e uma ex-colônia. Não persistiram, entre nós, as hostilidades encapuchadas, os arrufos, as desconfianças ou a falsa condescendência que dificultaram por muito tempo as relações entre os outros países americanos, de um lado, e a Espanha e a Grã-B retanha, de outro. Para isso, talvez tenham contribuído, de início, a circunstância de serem irmãos D. M aria II e D. Pedro II e, mais tarde, a continuidade de um fluxo migratório que, embora tenha esmaecido após 1960 - retomando, é bem verdade, força entre 1974 e 78, com os inconformados com o 25 de Abril e os expelidos da África pela descolonização -, nunca se estancou de vez.

O diálogo entre Portugal e o Brasil sempre foi entre iguais e não chegou a ser retorcido ou a perder o seu tom fraterno, nem mesmo durante os longos períodos caracterizados pela ausência de coincidência política, com regimes ou governos de signos contrários em cada um dos dois países - monarquia em Lisboa e república no R io de J aneiro, salazarismo, de um lado, e democracia, do outro, democracia em Portugal e autoritarismo no Brasil. As crises derivadas dessas diferenças e os naturais problemas que relações estreitas não podem deixar de periodicamente causar, foram sempre passageiros e não provocaram mais que arranhões superficiais no fluir de relações que se passam, mais que entre estados, entre povos que reconhecem antepassad os comuns e se reservam um para o outro o olhar de família.

Isto não cessa de causar espanto a nossos vizinhos americanos de língua castelhana: que o afeto forme o espaço dentro do qual se desenvolvem as relações entre Portugal e o Brasil. Que um português se ressinta, quando tratado como estrangeiro no Brasil, em vez de como potencialmente um brasileiro, isto é, um português. Ou o brasileiro, se não o acolhem em Portugal na condição a que julga ter direito por herança de sangue ou cultura, a de brasileiro, ou um quase português.

A natureza singular, única, das relações entre brasileiros e portugueses talvez indique termos diante de nós duas espécies de um mesmo gênero, o dos luso- 
descendentes, para usar a palavra cunhada por António Sérgio. Durante mais de meio século, políticos, diplomatas e formadores de opinião têm trabalhado, por cima quase sempre de diferenças de regimes políticos e vencendo as resistências, ora de um lado, ora do outro, da desconfiança, da cautela e da descrença, para dar forma jurídica a essa realidade que só escapa a quem tapa os olhos porque a não quer ver. M uito já se conseguiu avançar nessa obra em construção, e tanto, que ela se mostra a outros povos original e exemplar. Os últimos passos foram dados pelos constituintes brasileiros de 1988, quando, na nova Carta Magna, estabeleceram que ao português residente no Brasil seriam atribuídos os direitos inerentes ao brasileiro nato, com apenas seis exceções, pois não pode ser ele presidente e vice-presidente da R epública, presidente da Câmara dos Deputados e do Senado, ministro do Supremo Tribunal Federal, diplomata e oficial das Forças Armadas. Essa ampliação dos direitos políticos do português que mora no Brasil - onde pode votar e ser votado, tomar assento no parlamento federal, nas assembléias legislativas estaduais e nas câmaras municipais, ser governador de estado e prefeito - só depende de que seja assegurada a reciprocidade ao brasileiro que viva em Portugal.

Embora, nas duas vezes em que o assunto foi submetido aos legisladores portugueses, essa reciprocidade não tenha sido alcançada, estou convencido de que não poderá deixar de ser concedida, e dentro de poucos anos. Minha convicção decorre de outra, mais profunda, a de que Portugal, o mais antigo de todos os estados europeus e o mais coeso dentro de suas fronteiras, não se resignará repito - a ser apenas uma província a mais, ainda que próspera e influente, da E uropa. Não consigo vislumbrar um Portugal que seja uma espécie de Países Baixos, que abdicaram da aventura e dela só deixaram algumas páginas na história em uma história com pouca, se alguma, vinculação com o presente, pois da Indonésia e até do Suriname não se pode dizer que compartilhem com a Holanda a mesma cultura nem que se ponham juntos em seus projetos de destino. E tenho por impensável um Portugal a ajustar-se ao papel que poderão vir a ter uma E scócia ou uma Catalunha, numa E uropa das nacionalidades.

Assim julgo, porque não vejo Portugal como um país pequeno. Será pequeno na geografia, mas é enorme na história. E numa história viva, porque se prolonga na hora atual e se arremessa no futuro. É a história de uma nacionalidade numerosíssima, que se foi distribuindo numa amplíssima geografia - todos os continentes -, ao longo de oito séculos - quase um milênio - , e tomou a forma de povos que, ou se reconhecem, com suas diferenças, na unidade essencial da mesma cultura, como ocorre naquelas partes em que os portugueses não tiveram apenas feitorias, mas, com seus mestiços, ocuparam e fizeram suas, como o $\mathrm{B}$ rasil e Cabo Verde, ou se têm como herdeiros de muitos de seus valores essenciais, como 
Angola, G uiné-Bissau, M oçambique, São Tomé e Príncipe e, se Ihe for permitido, Timor.

Portugal fica na E uropa. Comparte sua história e sua mundividência. É dela sócio na construção de sua unidade. E nela possui interesses fundamentais. Mas Portugal é a proa do continente - e pertence aos oceanos. Sem os oceanos, Portugal se amesquinha. Se sua bússola apontasse para o futuro, indicaria - disto estou persuadido - que a boa rota dependerá não apenas dele e do que for na E uropa, mas do que se fizerem os demais países que falam, pensam, sentem, se comovem e convivem em português. E sse futuro será afetado também pela forma e a dimensão que cada estado de língua portuguesa souber imprimir às suas relações bilaterais com os demais e ao empenho com que atuar no seio do que se quer uma comunidade de nações.

Talvez caiba aqui uma advertência. Não deve Portugal - nem, de resto, o B rasil, Angola ou G uiné-B issau - colocar todos esses países na mesma mochila. J á é mais que hora de relegar-se ao depósito de trastes inúteis a sigla PAL OP e tratar cada nação africana como uma realidade única, específica e a merecer atenção política própria.

Nada mais equivocado do que aplicar-se a Cabo Verde a mesma medida que a Angola. Há entre os países de língua portuguesa, descontados o traço-de-união do idioma e as coincidências da história, grandes diferenças. Para começar pela mais simples, é imensa a desproporção territorial e populacional entre o B rasil, de um lado, e, do outro, Guiné-Bissau ou São Tomé e Príncipe. Cabem quase sete Angolas dentro do mapa brasileiro, e onze M oçambiques. Cabo Verde e São Tomé e P ríncipe são arquipélagos, enquanto que os demais estão engastados em continentes. Todos pertencem ao Atlântico, menos um, M oçambique, que fica geográfica e culturalmente no Índico e possui, como também a G uiné-B issau, forte presença islâmica. Do ponto de vista econômico, é enorme o hiato entre seus graus de desenvolvimento. Suas estruturas são tão distintas, que pode mudar a quantidade dos algarismos utilizados na medição do produto nacional e da renda per capita, quando se passa de um para outro. Contrastes semelhantes verificam-se em quase todos os planos da organização social. E até no levantamento das potencialidades e na dimensão dos problemas.

As dessemelhanças são também evidentes no âmbito do idioma. E m Portugal e no B rasil, o português é a língua do berço e da infância. E m Cabo Verde e em São Tomé e Príncipe, os falares maternos são os respectivos crioulos, que competem com o português como língua veicular. E m G uiné-B issau, a situação é mais complexa: em certas porções do país ( sobretudo nos arredores da capital) , a comunicação dá-se, no seio das famílias, em crioulo, mas, na maior parte do território, o vernáculo é uma das várias línguas africanas, disputando o português com o crioulo a con- 
dição de língua franca. J á em Angola e Moçambique, o português é o falar materno de pequenas minorias urbanas, enquanto o grosso da população se relaciona, em casa e na vizinhança, num dos diferentes idiomas bantos. Mas, em ambos os países, o português é cada vez mais usado como língua franca, como a segunda língua de todos, e é um instrumento de convivência social e de unidade política.

Se assistimos, nos dias de hoje, a uma crescente valorização dos vernáculos falados por grupos pouco numerosos, como fator de comunhão entre seus membros e de preservação de seus valores, presenciamos também a expansão e o fortalecimento dos idiomas veiculares, e não só dos nacionais, mas sobretudo dos transnacionais. A difusão da imprensa, do rádio, da televisão e da Internet, a freqüência das viagens de comboio, automóvel e avião, bem como a facilidade e a universalidade das comunicações, que tornaram atos corriqueiros o falar por telefone ou o trocar informações e idéias por correio eletrônico, tendem a reduzir as diferenças regionais e as variantes nacionais de um idioma e a forçar um número cada vez maior de indivíduos a expressar-se, quase quotidianamente, em uma ou em duas outras línguas que não a de uso doméstico.

Tudo indica que serão poucos, no futuro, os grandes idiomas de cultura e de entendimento transnacional. Entre os requisitos para uma língua manter-se nesse patamar ou a ele ascender não se contarão apenas sua riqueza vocabular, sintática e expressiva, sua ductilidade, sua plasticidade, seu pendor ou aptidão para renovar-se, a fim de acompanhar as mudanças do mundo e ser capaz de exprimilas, mas também a amplitude de sua disseminação numérica e geográfica e o poder relativo que os seus utentes detenham no concerto das nações.

Tanto o inglês quanto o castelhano e o francês são idiomas oficiais de numerosos países e falados em vários continentes; o russo, apesar da quantidade dos que nele se expressam, não conseguiu jamais sair das fronteiras de um império contíguo; o árabe e o chinês apresentam na linguagem falada diferenças tão marcadas, que lhes roubam a unidade; o alemão não se popularizou fora da chamada Europa Central; o hindi não conseguiu tornar-se a língua franca da União Indiana. N essa competição, o português apresenta-se com vantagens e desvantagens. Em seu favor, contam-se a unidade do idioma, que as variantes nacionais não afetam, o ser a língua oficial de sete nações soberanas, em três continentes, e o ser utilizado por 200 milhões de pessoas. Mais de 3/4, ou quase 4/5 dos lusoparlantes vivem, porém, num só país, o Brasil, e fora dele e de Portugal, não logrou a língua portuguesa tornar-se aquela em que todos podem comunicar-se e entender-se.

Não bastarão, para que um idioma se afirme como de vigência internacional, o número e a distribuição dos que o falam. I mporta, claro, ser o inglês usado como primeira ou segunda língua por cerca de 700 milhões de indivíduos. Mas se, em 
todo o mundo, se estima existirem 100 milhões de pessoas de outros idiomas que podem expressar-se em inglês com absoluta fluência e um número muitíssimo maior de indivíduos que o conseguem ler e entender, isto se deve sobretudo ao papel hegemônico que tiveram no mundo, no último par de séculos, dois países de língua inglesa - primeiro, a Grã-Bretanha e, depois, os Estados Unidos. Foram eles proeminentes em quase todos os planos: no político, no militar, no econômico, no científico, no literário, no artístico, no desportivo, no da divulgação de notícias e idéias e até no das diversões populares. Estuda-se o inglês - e crê-se que, neste momento, cerca de um bilhão de pessoas procuram de algum modo aprendêlo - porque dá acesso às informações mais recentes sobre o campo de conhecimento que nos interessa, porque nos abre o diálogo com pessoas de idiomas que não estão ao nosso alcance, porque melhora o nosso conhecimento do mundo e, em última análise, amplia nossas possibilidades profissionais de êxito.

A volta do português à condição de idioma de trânsito internacional - como foi no passado, do século XVI à metade do XVIII, quando não se comerciava na África Ocidental e em muitos portos do Índico sem saber-se português ou sem ajuda de quem o soubesse - , dependerá do que forem capazes de ser e produzir, com relevância para os outros povos, Angola, B rasil, Cabo Verde, Guiné-B issau, M oçambique, Portugal e São Tomé e Príncipe. Do que neles criarem a inteligência, a imaginação e a sensibilidade. Do que se inventar nos seus laboratórios e se pensar nas suas universidades. Mas, sobretudo, da riqueza que gerarem, do tamanho de seus mercados e da importância política que vierem a ter em seus sistemas regionais e no concerto internacional, juntos e isolados.

É o poder que forma os cânones. Se o B rasil já ocupasse o lugar para o qual parece endereçado, Camões seria lido, ao menos na E uropa e nas A méricas, com a obrigatoriedade que tem Shakespeare, Cruz e Sousa estaria nas estantes ao lado de Whitman, Santos-D umont seria reconhecido como o principal inventor do avião, E ça de Queirós e M achado de Assis emparelhariam com M elville e Henry J ames, Colombino receberia atenção semelhante à que é dada a Winslow Homer, e VillaLobos seria tão ouvido quanto Copland ou B ritten.

Da perspectiva dos outros, o que somos é o que dá importância ao que fomos. Mas não, da nossa. Entre as certezas que temos, figura a de que o nosso rumo começa num desenho do passado. $E$, havendo esse passado se composto de audácias e perigos, intensidade e grandeza, ele nos impõe, a portugueses e brasileiros, uma agenda da qual não podem ausentar-se os compromissos que assumimos como navegador, bandeirante, pioneiro e colono. Pelo que a história nos fez, há que pagar, agora e sempre, um preço.

Na pauta das relações entre Portugal e o Brasil, não há como evitar que este item se empurre para a primeira linha: o de fazer-se do idioma oficial comum o 
principal vínculo entre os países que, hoje soberanos, foram um dia parte do mesmo império, como metrópole e como colônias.

Tal qual sucedeu, a partir da metade do século XIX, com o B rasil, embora de modo surpreendentemente mais rápido do que fariam prever os contrastes, em forma e violência, com que processaram as rupturas descolonizadoras na A mérica e na África portuguesas, vão-se recolhendo à história, transformados em avantesmas ou desenhos de pesadelos, em remorsos para um e cicatrizes dolorosas para os outros, a indignação, a animosidade, a repulsa e o rancor com que os africanos encaravam Portugal. Não que se tenham apagado as memórias perversas da guerra, nem as lembranças, mais antigas e mais profundas, das humilhações impostas à cor de suas peles e às suas culturas. Nas pranchas gravadas foram-se, entretanto, raspando muitas das hachuras que as sombreavam, deixando ver, aqui, ali, acolá, entre o confronto e a coação, outras imagens de um trato multissecular, a que não faltaram os laços de família e as resultantes mestiçagens, a adesão de não poucos colonos aos valores da terra e a solidariedade de tantos portugueses aos que sabiam maltratados ou, pela gente da M etrópole, desmerecidos.

Passado o fugaz ajuste de contas, ao que se aspira é retomar com outro fio as costuras de uma história, na qual a intrusão dos portugueses entre povos que deles eram tão diferentes resultou em novas composições culturais e em novos espaços políticos, em novos estados que se vinculam entre si sobretudo pelo idioma do adventício.

É esta língua, a portuguesa, o que nos singulariza. Somos um país europeu, um país americano e cinco países africanos, a viver a realidade de nossos respectivos continentes, a ter neles interesses imediatos e a participar de diferentes esquemas de integração econômica, mas somos também - e talvez o venhamos a ser principalmente - os países onde se fala o português. Trata-se aqui de um outro círculo, que, em vez de colidir, pode e deve harmonizar-se com os demais, um outro círculo de atuação externa de cada um de nossos governos, porém mais ainda, de nossos povos. E vai ele ganhando expressão numa nova Comunidade, a dos Países de Língua Portuguesa, que, de sua base cultural, se quererá crescentemente econômica e política.

Para o Brasil, sobressai outro ponto na agenda: o de que se igualem os direitos de que desfrutam os brasileiros em Portugal aos de que gozam os portugueses no B rasil; e não só que se igualem, mas também que paulatinamente se ampliem. Essa prioridade afina-se com uma tendência, já clara no Brasil, de tornar-se o homem, o indivíduo, o cidadão de carne e osso, o objeto real da ação política. Essa preocupação crescente da diplomacia com cada um de seus nacionais vai-se revelando um necessário corretivo à propensão recente de muitos estados para negar 
ou obstruir certos direitos fundamentais da pessoa humana, como o de locomoverse livremente e o de buscar a felicidade onde deseje. Nos casos do Brasil e de Portugal, as restrições ao ir e vir, e à validade dos diplomas, e ao exercício das atividades profissionais embatem numa tradição que teria de ser fortalecida, em vez de contrariada.

Desde que pela primeira vez alguém de si mesmo disse ser brasileiro, brasileiros moram em Portugal. Saíam do Brasil para estudar, para reunir-se a tios e avós, para cuidar de propriedades que herdaram, para acompanhar marido ou mulher, para representar interesses mercantis da família, para trabalhar nas mais diversas profissões, para abrigar-se dos dissabores políticos, para escavar raízes ou perseguir sonhos. Alguns viajavam meninos; outros, adolescentes; esses, já adultos; aqueles, para o repouso da reforma, numa terra - repito, porque é bom que se insista - que tinham também por deles e onde só se entristeciam, irritavam ou indignavam, quando lhes chamavam estrangeiros.

Sempre houve por volta de uma dezena de milhares de brasileiros em Portugal. M édicos, advogados, comerciantes, jornalistas, artistas e homens de ciência, eles desceram o Chiado e transitaram pela Rua Nova dos Ingleses durante todo o Oitocentos e as primeiras décadas de nosso século. Muitos fizeram nome. E vários segmentaram suas existências entre as duas praias do Mar Oceano, alternando longas estadas num e noutro lado, a mudar-se de um para o outro país, saudosos do Brasil, em Portugal, e nostálgicos de Portugal, se no Brasil.

O que se apresenta como novidade - o afluxo, na década dos 80 , de brasileiros tangidos de seu país pelo castigo e as incertezas da inflação - não foi mais do que um capítulo de uma história antiga, quase tão antiga quanto a da transmigração de portugueses para o B rasil. Essa presença brasileira aumentou ou diminuiu, no correr do tempo, conforme as vicissitudes políticas ou econômicas, a moda, os reclamos espirituais de retorno à origem ou de mergulho no que vai mais profundo na alma de descendentes de imigrantes.

Novidade de fato é a multiplicação de exigências para que os brasileiros possam exercer suas profissões em Portugal. Tenho por quase impossível o justificar esses entraves à opinião pública de um Brasil que até há pouco, até que se avolumaram os obstáculos aos seus nacionais em Portugal, acolhia sem reservas os profissionais portugueses, fossem advogados, arquitetos, engenheiros ou médicos, reconhecia e ratificava automaticamente os seus diplomas e abria a porta de suas escolas e universidades aos que fossem professores, quer tivessem chegado como imigrantes ou como exilados do salazarismo ou do 25 de Abril.

Há que cumprir requisitos legais, não o ignora o brasileiro, mas sabe igualmente que a lei interna deve ajustar-se ao espírito dos tratados que nos irmanam e, em consonância com ele, ser interpretada. Se isto sabe, espera também que a 
diplomacia portuguesa deixe claro a seus parceiros da União E uropéia que não pode, dentro de seu território nacional, aplicar aos brasileiros o tratamento que se reserva aos estrangeiros. T êm Portugal e o B rasil compromissos contratuais bem mais antigos. E uma forma de enlace que, se não for especial e única em sua fraternidade, de pouco vale.

Giro a roda. Insisto. As relações entre Portugal e o B rasil são mais do que relações entre estados; são relações entre dois povos que reconhecem a mesma ascendência, que reivindicam os mesmos tetravós. Pois faz parte de uma minoria o brasileiro que não conta ao menos com um ancestral português. E é mais raro ainda aquele que não ancora o passado de sua alma, ou de parcela de sua alma, em Portugal. As relações entre os dois povos, ou são, por isso, fundamentalmente afetivas, ou se perdem nas tentativas de dar-Ihes substrato econômico.

É desejável e possível, sem dúvida, aumentar as trocas comerciais entre os dois países, e fazer crescer os investimentos recíprocos, e ampliar a cooperação técnica. Todos queremos isto e muito mais que isto. Se, porém, sobre esse tipo de interesses pretendermos levantar um edifício, vamos ficar com alicerces bem mesquinhos. Por mais que se expandam as exportações, dificilmente, pelas estruturas dos dois países e as circunstâncias de suas inserções no mundo, aparecerão elas com relevo nas suas estatísticas. Os números só poderiam tornar-se menos modestos e até importantes, se a economia portuguesa tomasse impulso no rumo da produção de artigos tecnologicamente de ponta, esteticamente requintados e de alto valor unitário, se sua rede de serviços passasse a representar de forma substancial interesses brasileiros na Europa ou a atuar como enlace entre empresas da U nião E uropéia e do M ercosul, se sua estrutura turística, ao favorecer a busca das raízes familiares e das matrizes culturais, tornasse o país um dos principais destinos dos grandes números de viajantes que saem do B rasil e só são superados pelos japoneses em volume de compras no exterior. M esmo que tudo isso viesse a verificar-se, não bastaria como matéria para amplos e bons alicerces. As fundações do entendimento entre Portugal e o B rasil têm de assentar-se, e se assentam, com outra argamassa.

Há que voltar, sem medo da pieguice ou da hipérbole, às grandes palavras. E também aos diminutivos, que são tão nossos. O que se impõe é aprofundar a intimidade fraternal entre os dois países, fazer valer permanentemente os parentescos atuais e históricos, firmar a confiança - por que hesitar em dizê-lo? - no bemquerer. Em relações balizadas pela saudade e pela utopia e nas quais, por isso mesmo, as decepções surgem geralmente de um não achar no outro o que nele pôs com a imaginação ou a esperança, não podem ser os interesses do mercado que Ihe sirvam de cimento, mas, sim, as criações da sensibilidade e da inteligên- 
cia, das Bachianas Brasileiras e da História Trági co-Marítima à musiquinha popular que se assobia na esquina.

Queremo-nos próximos, a conversar na mesma sala, mas atravessamos, contraditoriamente, um daqueles períodos de afastamento. Conto os brasileiros que já viram, fora do turbilhão das B ienais de São Paulo, um quadro do Vespeira, do Nikias Skapinakis, do M anuel Baptista, do J oão Vieira, do Eduardo Luiz, da Graça Moraes ou do Costa Pinheiro, e, no entanto, conheço, sem ter feito qualquer esforço para isso, uma dúzia de Malhoas e B otelhos comprados, em vida dos pintores, por cariocas e paulistas. Um que outro português terá ouvido uma das sinfonias de Cláudio Santoro. M as qual a companhia brasileira de teatro que está em temporada em Portugal? Quase com certeza, nenhuma, como nenhuma portuguesa, no B rasil. Quanto ao livro brasileiro, jamais foi ele bem distribuíd o no outro lado do mar, e o português não soube, após a Guerra, acompanhar o crescimento e as modificações do mercado brasileiro.

No fim da década dos 40 e início dos 50, ainda se encontrava - falo do Rio de J aneiro - na Livros de Portugal e no velho Antunes da R ua Larga muito do que se queria. Mas o livro já era procurado, em vez de ser oferecido. Lembro-me de que, se travei conhecimento com o Fernando Pessoa ele próprio e o R icardo R eis nas edições da Ática, li quase todo o Álvaro de Campos em cópias datilografadas que circulavam entre os rapazes. Guimarães Rosa e J oão Cabral de M elo Neto não teriam tido a audiência que lograram em Portugal, se não tivessem sido editados em Lisboa. E J osé Saramago não venderia o que felizmente vende no Brasil, se seus livros não saíssem dos prelos de São Paulo.

O produto cultural de cada um dos dois países não só não chega fisicamente ao outro, como pouco sabemos do que se está fazendo em cada uma das praias onde se fala o português. Salva-nos da cegueira o J L - J ornal de Letras, Artes e I déi as, de J osé Carlos de Vasconcelos, que não tem, contudo, equivalente brasileiro. Estamos, em matéria de comércio cultural, a léguas de onde já chegaram os anglo-saxões, como se pode verificar acompanhando uns seis números seguidos do Times Li terary Supplement e de The New York Revi ew of Books: quase metade do primeiro é dedicado a obras escritas nos Estados Unidos, e outro tanto do segundo, a livros saídos na G rã-B retanha. Não faltam sequer, e são cada vez mais freqüentes, as obras que têm por co-autores um britânico e um norte-americano. De quem a culpa que não seja assim em Portugal e no B rasil? Nossa. De todos nós. Que ficamos a nos olhar no espelho, em vez de nos debruçarmos à janela.

Não desconto ou desmereço outros problemas. Há mistérios na recepção do que um outro país produz - até mesmo quando o consumidor pertence ao mesmo espaço de cultura. Entre nós, as palavras passam diretamente da boca ao ouvido e da página impressa aos olhos, sem necessidade de intérprete e quase sem o uso de dicionário. 
E mbora nos incluamos todos no espaço maior da língua portuguesa, não devemos esquecer, no entanto, que cada uma de nossas nações desenvolveu cultura própria, ainda que sob influxo das outras, e por essa cultura se identifica e projeta. Cabo Verde é mestiço. O B rasil é, a um só tempo, mestiço e pluricultural; grande parte de sua carne e de sua alma é africana; o ameríndio, de tão presente, quase passa despercebido dentro dele; e, como se não bastasse, cada região, em grande parte pelas diferenças de amálgama, possui valores próprios e tradições que são só suas. O tecido de Angola é africano, sobre ele se bordando com linha portuguesa - e um ou outro ponto do B rasil. O próprio Portugal não escapou às misturas, pois foi, ao longo da história, enxertandose com o que encontrou na África, na Ásia e na América.

Procuramos com freqüência no nosso semel hante o que nele é diferente. Isso explicaria em parte o fascínio com que se lêem António Nobre e M iguel Torga no B rasil ou J orge Amado em Portugal, mas deixa sem resposta o por que um Alexandre O'Neill, tão singular em sua maneira de escrever o nosso idioma e de mostrar-se português, ficou no B rasil - como já se dera com Cesário Verde - um poeta de poetas. Caso distinto seria o de Mia Couto, cujas edições brasileiras foram recebidas com entusiasmo pela crítica, mas até agora não conquistaram os leitores, que continuam arredios e desconfiados, talvez porque ainda não esqueceram a insistência com que lhes procuraram impingir, em matéria de autores africanos, gatos por lebres, ou seja, políticos por poetas.

Mudam-se, bem o sabemos, de um país para outro os padrões de apreciação e valor. Entre o que produz o outro, elegemos por contraste ou afinidade. E nem sempre selecionamos o que aquele prefere ou pensa ter de melhor. O que é importante é que possamos escolher, porque conhecemos a oferta. E é isto o que está faltando e é urgente e prioritário corrigir. Se não formos capazes de encontrar nas livrarias e continuo a tomar modelos na literatura - os autores do presente, breve esqueceremos os do passado e, em Portugal, não mais se lerá M achado de Assis, nem, no Brasil, B ocage. E não é de mau agouro que já sejam tão pouco lidos?

Saber e compreender o que são e fazem todos e cada um dos que aspiramos a construir um espaço cultural, econômico, político e humano da língua portuguesa é o primeiro passo, e o mais importante, para começar a cumprir-se esse desiderato. E não se diga que isso não é prioritário, quando vemos organizada a francofonia, assistimos à expansão do castelhano e à crescente mobilidade, dentro da ampla área que ocupa, dos bens culturais que nela se produzem, e sabemos que os anglófonos, desde muito, se aglutinam politicamente em torno do idioma e da comunhão da cultura. Um pragmático lembraria sem demora a parceria privilegiada que se desenvolveu, no decorrer dos últimos cem anos, entre os E stados Unidos e o R eino Unido. Os pressupostos, os interesses e os objetivos de suas políticas externas podiam ser dissonantes e, muitas vezes, opostos, mas, nas ho- 
ras de crise, quando o destino de um deles parecia ameaçado, os vínculos do idioma comum e dos valores compartidos os alinharam solidamente.

Assim também, só nos fortalecerá, a Portugal e ao B rasil - e também a AngoIa, Cabo Verde, G uiné-B issau, M oçambique e São Tomé e Príncipe -, chegarmos juntos ao futuro. Cada qual a seu jeito, dentro de suas possibilidades e de suas circunstâncias. Mas de mãos dadas. Portugal, que foi fronteira de um mundo e princípio de outros, aglutinador de contrários e cabeça de império, tem a obrigação de fazer por isso e de cobrar dos demais que o também façam. 